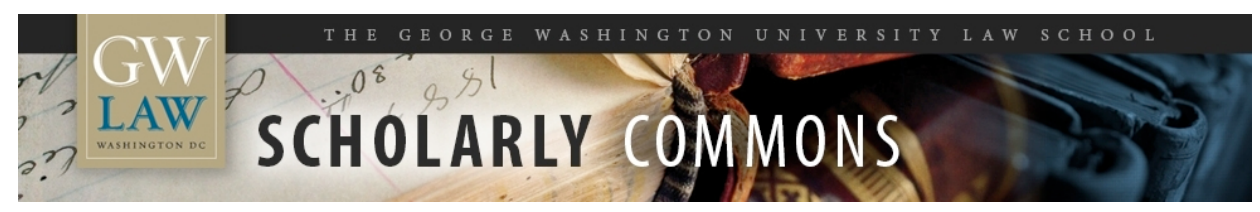

GW Law Faculty Publications \& Other Works

Faculty Scholarship

2020

\title{
Race and the Criminal Law Curriculum
}

Cynthia Lee

George Washington University Law School, cylee@law.gwu.edu

Follow this and additional works at: https://scholarship.law.gwu.edu/faculty_publications

Part of the Law Commons

\section{Recommended Citation}

Cynthia Lee, Race and the Criminal Law Curriculum in The Oxford Handbook of Race and Law in the United States (Carbado ed. forthcoming 2021 Oxford University Press)

This Chapter is brought to you for free and open access by the Faculty Scholarship at Scholarly Commons. It has been accepted for inclusion in GW Law Faculty Publications \& Other Works by an authorized administrator of Scholarly Commons. For more information, please contact spagel@law.gwu.edu. 


\section{RACE AND THE CRIMINAL LAW CURRICULUM}

\section{CYNTHIA LEE ${ }^{1}$}

Many law professors teach Criminal Law without any explicit acknowledgment of race and its impact on the criminal law. That is how my Criminal Law professor taught the course when I was in law school - and that was how I taught Criminal Law when I first started teaching.

Race, however, infuses so many aspects of the criminal justice system that to teach Criminal Law without any acknowledgment of race reinforces the fiction that criminal law is race-neutral and blind to racial difference-something that is just not true.

In this chapter, I briefly sketch a few places in the substantive criminal law course where law professors can include discussion of race to enrich students' understanding of the law. Undoubtedly, there are other places where discussions of race could be introduced. What is presented here is not meant to be exhaustive of all the ways in which race can be discussed in the criminal law classroom. Nonetheless, this book chapter should be a useful guide to both law professors who want their students to think critically about race in the context of the criminal justice system and students who seek to make racial interventions in Criminal Law classes in which professors take a colorblind approach. ${ }^{2}$

\section{$\underline{\text { Jury Nullification }}$}

Many professors start their Criminal Law course with a discussion of theories of punishment and basic principles of criminal law, including the requirement that the prosecution prove its case beyond a reasonable doubt. Some professors also include the concept of jury nullification when discussing basic principles of criminal law.

If one covers the concept of jury nullification, one might want to have students engage Professor Paul Butler's proposal calling for racially based jury nullification. Butler argues that African American jurors should engage in jury nullification in cases involving African Americans charged with non-violent crimes. ${ }^{3}$

To make his case, Butler notes that "one-third of African-American young men are under criminal justice supervision[,] . . over half of the women in state prison are African-American, and over half of the men in federal and state prisons are African-American." "Butler points out that their numbers in prison suggest African Americans-who constituted only 12 percent of the

\footnotetext{
${ }^{1}$ Cynthia Lee is the Edward F. Howrey Professor of Law at the George Washington University Law School. She thanks Casey Matsumoto and Riven Lysander for excellent research and editorial assistance. She also thanks her former administrative assistant, Prerna BalaEddy, for administrative and editorial assistance. Finally, she thanks Devon Carbado for inviting her to contribute to The Oxford Handbook of Race and Law in the United States.

${ }^{2}$ Edited excerpts from most of the resources discussed in this chapter can be found in CYNTHIA LEE \& ANGELA P. HARRIS, CRIMINAL LAW: CASES AND MATERIALS (4th ed. 2019). If you use any of our edited excerpts, please provide proper attribution by citing to our casebook.

${ }^{3}$ Paul D. Butler, Racially Based Jury Nullification: Black Power in the Criminal Justice System, 105 YALE L.J. 677 (1995); Paul D. Butler, Race-Based Jury Nullification: Case-in-Chief, 30 J. MARSHALL L. ReV. 911 (1997).

${ }^{4}$ Butler, Race-Based Jury Nullification: Case-in-Chief, supra note 3, at 912.
} 
total population at the time - are the most dangerous and most immoral people in the United States $^{5}$ when, in fact, many African Americans are in prison for non-violent drug offenses. ${ }^{6}$

Butler notes that a huge cost of having one out of every three young African American males under criminal justice supervision is a "lack of male role models and male income" and "a lack of marriage-eligible" men in the African American community. ${ }^{7}$ To combat this problem, Butler urges African American jurors to consider nullifying or voting to acquit in cases involving African American defendants charged with non-violent drug offenses. ${ }^{8}$

One does not have to agree with Butler's racial jury nullification proposal to recognize its value as a pedagogical tool to encourage critical thinking about race and the criminal justice system. If one assigns Butler's work, one can also assign Andrew Leipold's strong rebuttal to Butler's proposal so students can consider the arguments on both sides of the question. ${ }^{9}$

\section{Void-for-Vagueness Doctrine}

Many professors teach the void-for-vagueness doctrine in Criminal Law. Under this doctrine, a statute that either fails to give ordinary citizens fair notice of what conduct is criminal or gives law enforcement officers arbitrary and capricious discretion to arrest individuals violates due process. ${ }^{10}$ A number of United States Supreme Court cases expound on this doctrine and allow a discussion of the ways in which implicit racial bias can influence a police officer's decision to arrest.

For example, in Kolender v. Lawson, the Court struck down a California statute that required persons loitering or wandering on the streets to (1) present credible and reliable identification, and (2) account for their presence, when requested by a police officer under circumstances that would justify a Terry stop. ${ }^{11}$ The individual at the center of this case, Ed Lawson, was an African American male with dreadlocks who had been stopped over fifteen times prior to the arrest that

\footnotetext{
${ }^{5} / d$. at $911-12$.

${ }^{6}$ Id. at 920.

${ }^{7}$ Id. at 916.

${ }^{8}$ Id. at 920-21. In his later book, Let's Get Free: A Hip-Hop Theory of Justice, Butler extended his proposal, urging all jurors, not just African American jurors, to vote not guilty whenever any "defendant is accused of possessing drugs for his or her own use, or selling a small quantity to another consenting adult." PAUL BUTLER, LET'S GET FREE, A HIP-HOP THEORY OF JUSTICE 72-73 (The New Press 2009). In other words, Butler urged jury nullification in cases involving minor non-violent drug possession and sale cases regardless of the race of the defendant or the race of the juror.

${ }^{9}$ Andrew D. Leipold, Race-Based Jury Nullification: Rebuttal (Part A), 30 J. MARSHALL L. ReV. 923 (1997).

${ }^{10}$ As the U.S. Supreme Court has explained, "Vagueness may invalidate a criminal law for either of two independent reasons. First, it may fail to provide the kind of notice that will enable ordinary people to understand what conduct it prohibits; second, it may authorize and even encourage arbitrary and discriminatory enforcement." Chicago v. City of Morales, 527 U.S. 41, 56 (1999) (finding Chicago's Gang Congregation Ordinance unconstitutionally vague). See also Joshua DRESSLER, UNDERSTANDING CRIMINAL LAW § 5.03 (7th ed. 2017) ("The Due Process Clause forbids the enforcement of any statute that, due to vagueness in language, 'vests virtually complete discretion in the hands of the police to determine whether the suspect has satisfied [its requirements].'”).

11 Kolender v. Lawson, 461 U.S. 352 (1983).
} 
led him to challenge the constitutionality of the California loitering statute. ${ }^{12}$ Suspecting that the main reason he was stopped so often by the police was his race, Lawson challenged the constitutionality of the California statute. ${ }^{13} \mathrm{He}$ argued that it gave officers too much discretion, and the Supreme Court agreed. Writing for the Court, Justice O'Connor explained why the statute was unconstitutional:

Section 647(e), as presently drafted and as construed by the state courts, contains no standard for determining what a suspect has to do in order to satisfy the requirement to provide a 'credible and reliable' identification. As such, the statute vests virtually complete discretion in the hands of the police to determine whether the suspect has satisfied the statute ... We conclude $\S 647(\mathrm{e})$ is unconstitutionally vague on its face because it encourages arbitrary enforcement by failing to describe with sufficient particularity what a suspect must do in order to satisfy the statute. ${ }^{14}$

Justice O'Connor did not address the role that implicit racial bias may have had in Lawson's being stopped in the first place. Her analysis in the case was thus consistent with her overall color-blind jurisprudence. ${ }^{15}$ A professor interested in calling attention to race, however, could use Kolender v. Lawson to highlight the racial implications of vague loitering laws by highlighting the way in which implicit racial bias can encourage people in general to associate African Americans with crime and police officers in particular to stop Black individuals more often than individuals who are not Black. ${ }^{16}$

L. Song Richardson's article, Arrest Efficiency and the Fourth Amendment, helps students understand this point. Using the science of social cognition, Richardson explains why a well-meaning officer might perceive the behavior of a Black person as suspicious even though the officer would not regard the same behavior by a White person as suspicious:

12 Leon Lindsay, Can a Person be Free to Wander Without Worry of Arrest?, CHRISTIAN SCI. MonITOR, May 12, 1982, at 3. Lawson was a vegetarian who strongly believed in the benefits of mental and physical fitness and, therefore, walked almost everywhere. Id.

${ }^{13} / d$.

${ }^{14}$ Kolender, 461 U.S. at 358.

${ }^{15}$ See Devon W. Carbado, (E)Racing the Fourth Amendment, 100 MıCH. L. ReV. 946, 977-80 (2002) (critiquing Justice O'Connor, who wrote the opinion in Florida v. Bostick, for ignoring the fact that Bostick was Black and the two officers who searched him were White and noting that in adopting a color-blind position, Justice O'Connor was not being race neutral, but was signaling that, in her opinion, race was irrelevant to the Fourth Amendment analysis, consistent with her color-blind approach in other cases).

${ }^{16}$ The author purposely capitalizes the words "Black" and "White" except where the words are lower case in quotations. See Kwame Anthony Appiah, The Case for Capitalizing the B in Black: Black and White are Both Historically Created Racial Identities-And Whatever Rule Applies to One Should Apply to the Other, ATLANTIC (June 18, 2020), https://www.theatlantic.com/ideas/archive/2020/06/time-to-capitalize-blackand-white/613159/ (https://perma.cc/ER4S-JVUD) (explaining why it is important to capitalize the words "Black" and "White" when referring to Black and White people); Lori L. Tharps, The Case for Black With a Capital B, N.Y. TIMES (Nov. 18, 2014), https://www.nytimes.com/2014/11/19/opinion/the-case-for-black-with-a-capital-b.html?smid=tw-share\& $r=1$ () (explaining that "[w] hen speaking of a culture, ethnicity or group of people, the name should be capitalized."); Brooke Seipel, Why the AP and Others Are Now Capitalizing the 'B' in Black, THE HILL (June 19, 2020, 05:25 PM EDT), https://thehill.com/homenews/media/503642-why-the-ap-and-others-arenow-capitalizing-the-b-in-black (https://perma.cc/WE6C-KQPU). 
The science of implicit social cognition demonstrates that individuals of all races have implicit biases in the form of stereotypes and prejudices that can negatively and nonconsciously affect behavior towards blacks. The implicit stereotype consists of the cultural stereotype of blacks, especially young men, as violent, hostile, aggressive, and dangerous. In the policing context, implicit stereotypes can cause an officer who harbors no conscious racial animosity and who rejects using race as a proxy for criminality to unintentionally treat individuals differently based solely upon their physical appearance.

As a result of implicit biases, an officer might evaluate behaviors engaged in by individuals who appear black as suspicious even as identical behavior by those who appear white would go unnoticed. In other words, even when officers are not intentionally engaged in conscious racial profiling, implicit biases can lead to a lower threshold for finding identical behavior suspicious when engaged in by blacks than by whites. ${ }^{17}$

Paul Butler's essay, Walking While Black: Encounters with the Police on My Street, makes a similar point through first person narrative. In this essay, Butler, an African American male law professor, recounts the night that he was stopped, questioned, and followed by D.C. police officers while he was walking home. ${ }^{18}$ Students often tell me that Butler's Walking While Black was the most memorable and impactful article they read during the semester.

Another case that illustrates the role of implicit racial bias in the exercise of police discretion is the 2009 arrest of African American Harvard professor Henry Louis Gates. In Masculinities, Post-Racialism, and the Gates Controversy: The False Equivalence Between Officer and Civilian, Frank Rudy Cooper illustrates the discretion inherent in the Massachusetts disorderly conduct statute upon which a White police officer relied to arrest Dr. Gates in Dr. Gates's own home after responding to a potential break-in call. ${ }^{19}$ Cooper goes beyond the obvious racial implications of the case to explore the masculinity contest that took place between the officer and Dr. Gates.

Another useful reading when covering the void-for-vagueness doctrine is Devon Carbado's Predatory Policing. In this article, Carbado notes how easy it is for police officers to establish the requisite probable cause to arrest mostly poor people for violating vague crimes, such as loitering, sleeping in a public place, sitting or lying down in a particular public place, camping or lodging in a public place, panhandling, storing personal property in a public place without a permit, drinking in public, and removing trash from a bin. ${ }^{20}$ This power to arrest-and concurrent power to engage in social control - sets into motion a chain of events that Carbado argues leads to mass criminalization of mostly poor Black and brown individuals.

\section{$\underline{\text { Hate Crimes and the Actus Reus Requirement }}$}

\footnotetext{
${ }^{17}$ L. Song Richardson, Arrest Efficiency and the Fourth Amendment, 95 MinN. L. ReV. 2035, 2039 (2011).

18 Paul Butler, Walking While Black: Encounters with the Police on My Street, LEGAL TIMES, Nov. 10, 1997 , at 23.

${ }^{19}$ Frank Rudy Cooper, Masculinities, Post-Racialism, and the Gates Controversy: The False Equivalence Between Officer and Civilian, 11 NeV. L.J. 1 (2010).

${ }^{20}$ Devon W. Carbado, Predatory Policing, 85 UMKC L. REV. 545 (2017).
} 
When Criminal Law professors teach the actus reus requirement, most focus on the voluntary act requirement, ${ }^{21}$ the unconsciousness defense, ${ }^{22}$ omission liability, ${ }^{23}$ and the prohibition on status crimes. ${ }^{24}$ In addition, some professors cover the criminal law principle that, as a general matter, one cannot be held criminally liable for bad thoughts alone. ${ }^{25}$ Students studying this principle often wonder why it is that a state can punish an individuals for a hate crime, which they might see as punishing a person for their hateful thoughts. A professor can address the distinction between thoughts and acts by assigning Wisconsin v. Mitchell, the seminal case on hate crimes. In this case, the Supreme Court explains that hate crimes are permissible because they punish a person for actions motivated by bias, not for hateful thoughts alone. ${ }^{26}$

\section{$\underline{\text { Voluntary Manslaughter and the Defense of Provocation }}$}

Most Criminal Law professors cover the defense of provocation, also known as the heat of passion defense. A defendant charged with murder who argues that he was provoked into a passion, can ask the jury to find him guilty, not of murder, but of a lesser offense, like voluntary manslaughter, because he killed while in a heat of passion. One arguing provocation must show he was spurred to action by legally adequate provocation.

At early common law, legally adequate provocation existed only if the defendant was provoked by certain things, including an aggravated assault or battery, mutual combat, an illegal arrest, the

\footnotetext{
${ }^{21}$ As a general matter, to be held criminally liable, one must engage in a voluntary act that causes social harm. See Martin v. State, 17 So.2d 427 (Ala Ct. App. 1944) (reversing the conviction of a man who was convicted of being drunk on a public highway because the defendant, while admittedly drunk, did not voluntarily appear in public in that condition); JoSHUA DRESSLER, UNDERSTANDING CRIMINAL LAW § 9.02 [A] (7th ed. 2015) ("Subject to a few limited and controversial exceptions, a person is not guilty of a crime unless her conduct includes a voluntary act"); WAYNE R. LAFAVE, 1 SUBST. CRIM. L. § 6.1(c) (3d ed. 2019) (noting that "it is clear that criminal liability requires that the activity in question be voluntary").

${ }^{22}$ See People v. Decina, 138 N.E.2d 799 (N.Y. 1956). Decina offers students the opportunity to analyze whether a person with epilepsy acts voluntarily if he drives into four schoolchildren during an epileptic seizure.

${ }^{23}$ Ordinarily, one cannot be held criminally liable for an omission or failure to act. See WAYNE R. LAFAVE, 1 SUBST. CRIM. L. § 6.2 (3d ed. 2019); MOdEL PENAL CODE $§ 2.01(3)$ (“Liability for the commission of an offense may not be based on an omission unaccompanied by action unless . . . the omission is expressly made sufficient by the law defining the offense; or . . . a duty to perform the omitted act is otherwise imposed by law."). One can be held criminally liable for an omission if one had a legal duty to act. WAYNE R. LAFAVE, 1 SUBST. CRIM. L. § 6.2(a) (3d ed. 2019). A legal duty to act may exist if a status relationship exists that imposes such a duty, the duty is imposed by statute or contract, one voluntarily assumes the duty, or one is responsible for creating the peril in the first place. See id. $\S 6.2(a)(1)-(5)$.

${ }^{24}$ Robinson v. California, 370 U.S. 660 (1962) ("We hold that a state law which imprisons a person thus afflicted [with narcotics addition] as a criminal, even though he has never touched any narcotic drug within the State or been guilty of any irregular behavior there, inflicts a cruel and unusual punishment in violation of the Fourteenth Amendment").

${ }^{25}$ WAYNe R. LAFAVE, 1 SUBSt. CRIM. L. $§ 6.1$ (3d ed. 2019) (noting that “[b]ad thoughts alone cannot constitute a crime").

${ }^{26}$ Wisconsin v. Mitchell, 508 U.S. 476 (1993).
} 
observation of the commission of a serious crime against a close relative of the defendant, or observation of one's spouse in the act of adultery. ${ }^{27}$

Virtually every single jurisdiction in the United States has abandoned the early common law approach to provocation, replacing it with a reasonable person test. Under this test, the defendant must show that a reasonable person in his shoes would have been provoked into a heat of passion. Legally adequate provocation is no longer confined to the five categories that were recognized at early common law but is defined in reference to the hypothetical reasonable person.

One categorical rule from the early common law approach, however, has persisted. Under the mere words rule, mere words can never constitute legally adequate provocation. This is because the law presumes that a defendant who kills in response to mere words is not reacting the way a reasonable person would react.

One could simply tell students about the mere words rule and move on, but the mere words rule has an interesting history. It turns out that the rule is not as absolute as it seems at first glance. Courts have consistently allowed male murder defendants to argue provocation in cases where the only thing that provoked them were mere words by their wives admitting to the commission of adultery or suggesting the husband's sexual inadequacy. ${ }^{28}$

In light of this gendered history allowing male defendants to argue provocation even when the provocation came from mere words, one avenue for fruitful discussion regarding race is the question of whether African American defendants charged with murder should be permitted to argue provocation if what provoked them was being called the $\mathrm{N}$-word. Camille Nelson has argued that Black defendants who have suffered years of racial discrimination and racially derogatory insults should be allowed to argue they were reasonably provoked into a heat of passion after being called the N-word. ${ }^{29}$ One can ask one's students whether they think courts should permit African American defendants charged with murdering someone who called them the N-word to argue provocation, just as they have done with male defendants charged with murdering their wives, even though those defendants were provoked by mere words. It is important to remind students that being allowed to make a provocation argument does not mean

\footnotetext{
27 JOSHUA DRESSLER, UNDERSTANDING CRIMINAL LAW §31.07[B][2][a] (7th ed. 2015). It is noteworthy that only husbands could benefit from the last category of legally adequate provocation, so perhaps a more accurate way of describing this last category would be the observation by a husband of his wife in the act of adultery. CYNTHIA LEE, MURDER AND the Reasonable Man: PASsion And Fear in the Criminal Courtroom 22 (NYU Press 2003) (discussing a Texas case in which the Court of Appeals refused to apply a Texas statute that made homicide justifiable when a husband killed a man upon finding that man in the act of adultery with the husband's wife to a woman who was charged with murder for shooting and killing her husband's mistress after catching them in the act of adultery).

${ }^{28}$ See People v. Berry, 556 P.2d 777 (Cal. 1976) (finding that a defendant who strangled his wife to death after she "sexually arous[ed] him and taunt[ed] him into jealous rages" was entitled to a provocation instruction on voluntary manslaughter); People v. Ambro, 505 N.E.2d 381 (III. App. Ct. 1987), overruled by People v. Chevalier, 544 N.E.2d 942 (III. 1989) (finding that a defendant who stabbed his wife to death after "she informed him of her adultery and then goaded him to kill her" was entitled to a provocation instruction on voluntary manslaughter). ${ }^{29}$ Camille A. Nelson, (En)raged or (En)gaged: The Implications of Racial Context to the Canadian Provocation Defense, 35 U. RICH. L. REV. 1007, 1053 (2002).
} 
one will succeed in convincing the jury that one was reasonably provoked. It simply provides the opportunity to make the argument.

\section{$\underline{\text { Involuntary Manslaughter }}$}

Many criminal law casebooks include State $v$. Williams. ${ }^{30}$ In this case, a Native American couple was charged with and convicted of manslaughter in the death of their infant child. According to the trial court's findings of facts, the parents had known that their seventeen-month-old child was ill but did not realize how sick he was. They simply thought he had a toothache and gave him some aspirin, thinking that would help. They did not take the baby to a doctor because they feared that the Welfare Department would take him away from them.

At the time this case was decided, the state of Washington allowed a manslaughter conviction on a showing of simple or ordinary negligence. ${ }^{31}$ The Williams case thus allows for a rich discussion of whether the young Native American parents (the husband was a twenty-four year old laborer with a 6th grade education and his wife was just twenty years old with an 11th grade education) acted reasonably in failing to take the child to the doctor. In a Note following this case in our Criminal Law casebook, Angela Harris and I invite the reader to consider whether, when trying to decide whether a defendant's actions conformed to those of a reasonable person, the jury should consider race, ethnicity, class, age, gender, or level of education. ${ }^{32}$

To encourage the students to think about the situation from the perspective of a Native American parent, we include an excerpt from the Indian Child Welfare Act of 1978, which reveals that around the time the Williams case was decided, approximately 25 to 35 percent of all Native American children were separated from their families and placed in foster homes, adoptive homes, or institutions. ${ }^{33}$ The Act specifically notes that "[i]n the state of Washington, the Indian adoption rate is 19 times greater and the foster care rate 10 times greater [than the non-Indian rate]." 34

\footnotetext{
${ }^{30}$ State v. Williams, 484 P.2d 1167 (Wash. Ct. App. 1971).

${ }^{31} \mathrm{ld}$. at 1171 (noting that manslaughter is committed if "the death of the victim is the proximate result of only simple or ordinary negligence").

32 Cynthia lee \& Angela P. Harris, Criminal law: CaSes and Materials 398-99 (4th ed. 2019).

${ }_{33}$ INDIAN CHILD Welfare ACt OF 1978, P.L. 95-608 HOUSE RePORT No. 95-1386 (July 24, 1978).

${ }^{34} \mathrm{Id}$. The Act notes that "the dynamics of Indian extended families are largely misunderstood. An Indian child may have scores of, perhaps more than a hundred, relatives who are counted as close, responsible members of the family. Many social workers, untutored in the ways of Indian family life or assuming them to be socially irresponsible, consider leaving the child with persons outside the nuclear family as neglect and thus as grounds for terminating parental rights." Id. The Act also notes, "One of the grounds most frequently advanced for taking Indian children from their parents is the abuse of alcohol. However, this standard is applied unequally. In areas where rates of problem drinking among Indians and non-Indians are the same, it is rarely applied against nonIndian parents. Once again cultural biases frequently affect decision making." Id. One can also assign a podcast episode from NPR's All Things Considered, entitled, Native Foster Care: Lost Children, Shattered Families (Oct. 25, 2011, 12:01 PM), https://www.npr.org/2011/10/25/141672992/native-foster-care-lost-children-shattered-families [https://perma.cc/CH9V-3B86] (discussing the fact that 32 states are not in compliance with the Indian Child Welfare Act of 1978's directive that Native American children must be placed with their relatives or tribes except in the rarest of circumstances, and that states must do everything it can to keep native families together).
} 
We also include a Note referencing the work of Jennifer Collins who conducted a study of fatal neglect cases brought against parents or guardians. ${ }^{35}$ Collins found that class seemed to affect which parents ended up being prosecuted, with preferential treatment being given to middle and upper class parents over parents who were unemployed or in blue collar positions. ${ }^{36}$

$\underline{\text { Rape }}$

Another area where one can call attention to race is the law of rape. When I teach rape, I usually start by informing my students that, as a historical matter, Black men who engaged in sexual intercourse with White women were often charged with and convicted of rape. ${ }^{37}$ This was in part due to social norms that made it taboo for White women to socialize with Black men. It was also partially due to deeply entrenched racial stereotypes about Black men as sexual predators. ${ }^{38}$ Indeed, before the Supreme Court ruled in Coker v. Georgia that imposing the death penalty for the crime of rape violated the Eighth Amendment's prohibition against cruel and unusual punishments, Black men convicted of raping White women received the death penalty more often than White men convicted of raping White women, Black men convicted of raping Black women, and White men convicted of raping Black women. ${ }^{39}$

In addition to our long history of seeing Black men as sexual predators, our country also has a long history of disbelieving Black women when they have been raped, stemming from stereotypes about Black women as being overly promiscuous. ${ }^{40}$ Indeed, these kinds of stereotypes likely contributed to the ability of White slave masters and their sons to rape their Black female slaves with impunity. ${ }^{41}$ Highlighting this history provides important historical context for law students studying the law of rape.

\footnotetext{
35 Cynthia lee \& Angela P. Harris, Criminal laW: Cases and Materials 400-01 (4th ed. 2019).

36 Jennifer M. Collins, Crime and Parenthood: The Uneasy Case for Prosecuting Negligent Parents, 100 NW. U. L. REV. 807, 809, 831-32 (2006).

37 Estelle B. Freedman, Redefining rape: SeXual Violence in the era of Suffrage AND Segregation 272, 288 (Harv. Univ. Press 2013) (observing that "[f]or most of American history, rape had been defined either in law or through practice as a crime committed largely by African American men against chaste white women" and noting that "[d]uring the decade after World War II, for example, African American men in Chicago were over five times more likely than white men to be prosecuted for rape; when convicted, they received longer sentences").

38 See Angela Y. Davis, Rape, Racism and the Capitalist Setting, 9 BLACK SCHOLAR 25, 27 (1978) (discussing the fictional image (or myth) of the Black man as rapist).

${ }^{39}$ Angela Davis notes that "of the 455 men executed between 1930 and 1967 for rape convictions, 405 of them were black"). Id at 24. See also BARRETT J. Foerster, RACE, RAPE, AND INJUSTICE: DOCUMENTING AND CHALLENGING DEATH PENALTY CASES IN THE CIVIL RIGHTS ERA 72-73 (2012) (describing a 1966 multistate survey that examined 1,238 rape convictions from seven states and found that "of the blacks convicted of raping white women, 36 percent were sentenced to death" while "[o]f the defendants in other racial combinations, only 2 percent received death verdicts"). Foerster notes that the study found that "Black defendants whose [rape] victims were white were eighteen times more likely to be sentenced to death than the [rape] defendants in other racial combinations." Id. at $70,73$.

${ }^{40}$ See supra Davis, note 38, at 27 (noting that "[t]he fictional image of the black man as rapist has always strengthened its inseparable companion: the image of the black woman as chronically promiscuous").

${ }^{41}$ See Osagie K. Obasogie, Anything But a Hypocrite: Interactional Musings on Race, Colorblindness, and the Redemption of Strom Thurmond, 14 YALE J.L. \& FEMINISM 451, 451, 473-74 (2006) (noting that "[b]oth the law of South Carolina and the power dynamics between Black women and White men during the Jim Crow era suggest
} 


\section{The Doctrine of Self-Defense}

Another area where one can incorporate race into the criminal law curriculum is the doctrine of self-defense. Most criminal law casebooks include the case of Bernhard Goetz, a White man who was charged with attempted murder, assault, reckless endangerment, and unlawful possession of a firearm after shooting four Black youths on a subway after two of them approached and asked him for five dollars. ${ }^{42}$ Goetz later confessed to the police that his intent was to murder the youths. Despite strong evidence against him, Goetz was acquitted of all the charges except an unlawful possession of a firearm charge.

One can use the Goetz case to discuss how attorneys can covertly play on racial stereotypes. According to George Fletcher, who observed the trial, Goetz's attorneys referred to the African American male victims as "savages," "predators," and "vultures," which were code words to convey to the jury that the Black youths were criminals preying on innocent law-abiding citizens like Goetz. ${ }^{43}$ Goetz's defense attorneys also received permission from the judge to reenact the subway shooting scene, ostensibly to show the jurors the path of the bullets. Fletcher notes that the defense chose four large young Black men from the volunteer patrol group Guardian Angels to play the Black youth who were shot by Goetz, suggesting that the real purpose of the reenactment was to convey to jurors that Goetz's fear of the four Black youth was reasonable. ${ }^{44}$

When discussing self-defense, one can also use the more contemporary case involving Trayvon Martin, the unarmed African American teenager who was shot and killed by George Zimmerman in 2012. Before the shooting, Zimmerman had called 911 to report what he thought was suspicious activity. The dispatcher asked Zimmerman if he was following the suspicious person. When Zimmerman responded affirmatively, the dispatcher told him, "Okay, we don't need you to do that." $" 45$

Martin, who was unarmed, had been talking on his cell phone with his girlfriend when Zimmerman began following him in his car. Martin ran away from Zimmerman, who got out of his car to pursue Martin on foot. A scuffle ensued. Zimmerman claimed Martin punched him, got him on the ground, and sat on top of him. Zimmerman told police he shot Martin because he feared Martin was reaching for his gun and was going to kill him. Zimmerman's gun, however, was hidden inside the back waistband of his pants, calling into question Zimmerman's claim of self-defense. ${ }^{46}$ If Zimmerman was lying on the ground with Martin on top of him, as Zimmerman

that [former Senator Strom] Thurmond statutorily raped and/or sexually assaulted [Carrie] Butler," a teenage maid in Thurmond's parents' home who was likely 15 years old when Thurmond first had sexual relations with her).

42 People v. Goetz, 497 N.E.2d 41 (N.Y. 1986).

${ }^{43}$ George P. Fletcher, A Crime of Self Defense: Bernhard Goetz and the LaW on Trial 206 (U. Chi. Press 1988) (noting that Goetz's attorney Barry Slotnick referred to the Black youth as "the predators" on society, "vultures," and "savages," in a covert appeal to racial bias). The jury found Goetz guilty of criminal possession of a weapon in the third degree, but not guilty on all of the other charges. Id. at 198.

${ }^{44}$ Id. at 206-07.

${ }^{45}$ Cynthia Lee, Making Race Salient: Trayvon Martin and Implicit Racial Bias in a Not Yet Post-Racial Society, 91

N.C. L. REV. 1555, 1557 (2013).

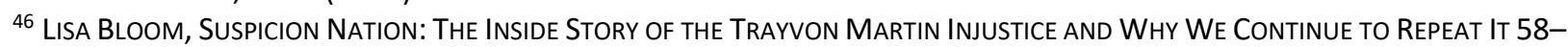
60 (Counterpoint Press 2014). 
claims, it would have been impossible for Martin to see Zimmerman's gun, let alone reach for it, unless Zimmerman had taken the gun out and pointed it at Martin. At that moment, Martin would have reasonably feared for his life and trying to grab the gun from Zimmerman would have been a reasonable action in self-defense.

The Martin case can be used to discuss the various ways in which racial bias can influence legal decision makers, including police officers deciding whether to arrest, prosecutors deciding whether to charge, and jurors deciding whether to convict. More specifically, one can invite students to consider how racial stereotypes about Black men as dangerous, violent criminals can influence legal decision makers evaluating a defendant's claim of self-defense.

To enhance this discussion, one can also inform one's students about social science research over the last several decades demonstrating that Black individuals are associated with dangerousness, violence, and criminality. In one study, for example, participants observed two men involved in a heated verbal altercation that ends when one man shoves the other man. When the shover was Black and the man being shoved was White, 75 percent of the participants thought the shove was "violent," while only 6 percent characterized it as "playing around." 47 In contrast, when the shover was White and the man being shoved was Black, 42 percent of the participants described the shover's actions as "playing around" and only 17 percent characterized the White man's shove as "violent." 48 The association of Black persons with danger and violence is so pervasive that many shooter bias studies have found that individuals are quicker to "see" a weapon in the hands of a Black person than they are to see a weapon in the hands of a White person, and that individuals will even "see" a gun in the hands of a Black person who is holding an object that is not a weapon. ${ }^{49}$

A professor wanting to highlight racial justice issues relating to the doctrine of self-defense might assign an excerpt from Addie Rolnick's Defending White Space. ${ }^{50}$ In this insightful article, Rolnick reveals the ways in which modern self-defense law reinforces racial subordination and helps maintain White residential segregation. ${ }^{51}$ Aya Gruber's Race to Incarcerate: Punitive Impulse and the Bid to Repeal Stand Your Ground is another article one might consider assigning. ${ }^{52}$ Gruber examines the history behind passage of Florida's stand your ground law and the messy evidence regarding its racial impacts.

\section{Black Rage}

\footnotetext{
${ }^{47}$ Birt L. Duncan, Differential Social Perception and Attribution of Intergroup Violence: Testing the Lower Limits of Stereotypes of Blacks, 34 J. PERSONALITY \& SOC. PSYCHOL. 590, 595 (1976).

48 Id.

${ }^{49}$ Cynthia Lee, Race, Policing, and Lethal Force: Remedying Shooter Bias with Martial Arts Training, 79 LAW \& CONTEMP. PROBS. 145 (2016) (examining shooter bias studies).

${ }^{50}$ Addie C. Rolnick, Defending White Space, 40 Cardozo L. Rev. 1639 (2019).

${ }^{51} \mathrm{Id}$. at 1690 (arguing that expanded self-defense laws "carve out the possibility for legalized lethal violence against people who appear 'out of place' and also create space for White residents to enact lesser forms of violence on their Black neighbors under cover of the same fear.").

${ }^{52}$ Aya Gruber, Race to Incarcerate: Punitive Impulse and the Bid to Repeal Stand Your Ground, 68 U. Miami L. Rev. 961 (2014).
} 
When teaching Criminal Law, most professors cover the traditional criminal law defenses, including self-defense, defense of others, imperfect self-defense, necessity, duress, insanity, the defense of provocation, and voluntary intoxication. In addition to these traditional criminal law defenses, a professor who wants to incorporate race into the criminal law curriculum can assign materials on what some call the "Black Rage" defense. As Paul Harris explains in his book, Black Rage Confronts the Law, the Black Rage defense "is not an independent, freestanding defense." ${ }^{53}$ Rather, the concept of Black Rage "merges racial oppression with more conventional criminal defenses." 54

An excerpt from Harris' book would be a good way to introduce students to the Black Rage defense. Harris explains how this defense was used in the case of Damian Williams and Henry Watson, two African American men charged in the beating of Reginald Denny, a White truck driver. On April 29, 1992, protests and riots broke out in many cities following the acquittal of four White police officers who had been caught on video brutally beating Rodney King, an unarmed Black man who was not physically resisting or posing any threat to the officers on all of the main charges against them. ${ }^{55}$

As Harris explains, that day, more than two thousand people had gathered to protest the acquittal in South Central Los Angeles. There was a confrontation between police and protestors at the intersection of Florence and Normandie Streets. After the police left, Denny happened to drive through that intersection. Some of the protestors threw bricks at the windows of Denny's truck, and as Denny came to a stop, the protesters pulled Denny from his truck and beat him. A television helicopter videotaped Damian Williams smashing a brick against Denny's head and Henry Watson pressing his foot on Denny's neck as Denny lay on the ground. ${ }^{56}$

Williams and Watson were charged with attempted murder, aggravated assault, and mayhem, among other offenses. At trial, Williams' attorney, Edi Faal, argued that Williams was not the person responsible for the beating. He also argued that even if the jury believed that Williams was the perpetrator, they should find him not guilty of the two most serious offenses, attempted murder and aggravated assault — both of which carried the possibility of a life sentence - because Williams lacked the specific intent to kill Denny. Faal explained that in light of the acquittals in the Rodney King case, Williams and others congregated to grieve together and express their disappointment in the verdict, and after a confrontation with the police, Williams was so consumed with emotion and frustration after experiencing years of discrimination as a Black man that when he took out his frustrations on Denny, he was not acting with the kind of reflective thought which would give rise to a specific intent to kill. ${ }^{57}$

Harris reports that "[a]t the end of Faal's closing argument, supporters in the courtroom stood and applauded, some even wept." 58 The jury deliberated for over two weeks. In the end, they

\footnotetext{
53 Paul harris, Black Rage Confronts the LaW 4 (NYU Press 1997).

54 Id.

$55 \mathrm{Id}$. at 184-85. The officers were acquitted despite the fact that the beating of the unarmed King while he was lying defenseless on the ground had been caught on videotape. Id. at 185.

56 Id. at $185-86$.

57 Id. at $186-87$.

58 Id. at 188.
} 
found Williams not guilty of attempted murder and aggravated assault, and guilty of simple mayhem and four misdemeanor assaults. ${ }^{59}$ Watson was also acquitted of attempted murder and convicted of misdemeanor assault. ${ }^{60}$ The jury deadlocked on the other charges against Watson, leading the judge to declare a mistrial on those counts. ${ }^{61}$

\section{The Cultural Defense}

Another way one can incorporate discussions of race and ethnicity into the criminal law curriculum is by covering what is commonly called the "Cultural Defense." There is no freestanding cultural defense, although some have argued for the establishment of such a defense. Defendants who are immigrants and defendants of color sometimes seek to introduce evidence about their cultural background to negate an element of the charged offense or mitigate the possible punishment. There is no established rule regarding the admissibility of cultural evidence in the criminal courtroom. Instead, judges have wide discretion to admit or exclude evidence regarding the defendant's cultural background depending on whether the judge thinks it is relevant.

In our Criminal Law casebook, Angela Harris and I include several readings on the cultural defense. ${ }^{62}$ We start with People v. Aphaylath, a case in which a Laotian refugee living in New York killed his Laotian wife of one month. ${ }^{63}$ At his murder trial, the defendant argued he was suffering from an extreme emotional disturbance because he believed that his wife preferred her ex-boyfriend over him and she had received phone calls from this man, which the defendant claimed brought shame upon himself and his family and triggered his loss of self-control. The defense tried to introduce expert testimony on the stress and disorientation Laotian refugees suffer when they come to the United States, but the trial court barred the testimony on the ground that the expert witnesses did not know anything about the defendant or his particular background and experiences. On appeal, the court reversed the defendant's conviction and ordered a new trial, finding that the exclusion of the expert testimony was erroneous since an expert witness does not have to have personal knowledge about a defendant or the defendant's particular characteristics. This case can be used to start a discussion on whether a defendant's cultural background is a relevant consideration in a criminal case.

In Cultural Evidence and Male Violence: Are Feminist and Multiculturalist Reformers on a Collision Course in Criminal Courts? ${ }^{64}$ Holly Maguigan discusses the tension between two

\footnotetext{
59 Id. at $188-89$.

${ }^{60}$ Cynthia Lee, Cultural Convergence: Interest Convergence Meets the Cultural Defense, 49 ARIZ. L. REV. 911,957 (2007), citing Edward J. Boyer \& John L. Mitchell, Attempted Murder Acquittal, Deadlock Wind Up Denny Trial, L.A. TIMES, Oct. 21, 1993, at A1.

${ }^{61}$ Id.

62 Lee \& HARRIS, CRIMinal LAW: CASES ANd MATERIALS (4th ed. 2019). For a defense of this casebook against the charge that it, along with other traditional criminal law casebooks, does not adequately prepare students for the practice of law, see Angela P. Harris \& Cynthia Lee, Teaching Criminal Law from a Critical Perspective, 7 OHIO ST. J. CRIM. L. 261 (2009) (responding to Anders Walker, The Anti-Case Method: Herbert Wechsler and the Political History of the Criminal Law Course, 7 OHIO ST. J. CRIM. L. 217 (2009)).

63 People v. Aphaylath, 502 N.E.2d 998 (N.Y. 1986).

${ }^{64}$ Holly Maguigan, Cultural Evidence and Male Violence: Are Feminist and Multiculturalist Reformers on a Collision Course in Criminal Courts?, 70 N.Y.U. L. Rev. 36 (1995).
} 
progressive groups, multiculturalists and feminists, over whether outsider criminal defendantspeople who are not from the dominant culture - should be allowed to present evidence about their cultural background. Maguigan notes that multiculturalists will often argue that such evidence should be admitted to even the scales of justice in a system that embraces the monolithic standards of the dominant culture. On the other hand, many feminists oppose the admission of such evidence on the ground that cultural evidence is often used to justify or excuse the physical violence by men against women. The Maguigan excerpt is an excellent way to get students to talk about these differing views of the wisdom of allowing evidence regarding the defendant's cultural background.

In (Mis)Identifying Culture: Asian Women and the "Cultural Defense," 65 Leti Volpp uses the Dong Lu Chen case, a case in which a Chinese immigrant used cultural evidence at his murder trial to receive a sentence of probation (as opposed to jail time), to critique the use of cultural evidence to excuse violence by immigrant men against immigrant women. Volpp explains that the Chen family immigrated to the United States in September 1986. Initially, Dong Lu Chen worked as a dishwasher in Maryland while his wife, Jian Wan, and their three children lived in New York. Chen began suspecting that Jian Wan was being unfaithful when she refused to have sex with him during one of his visits to New York. In June 1987, Chen moved to New York. In August of that year, he asked Jian Wan if she was seeing other men and she admitted that she was. In September, Chen told Jian Wan he wanted to have sex with her, but she declined and told him, "I won't let you hold me because I have other guys who will do this." Chen claimed that when she said this, his head became dizzy. When Jian Wan admitted that she had been cheating on him "for three months," he hit her head several times with a claw hammer before passing out.

At his murder trial, Chen's defense attorney presented an anthropologist, Burton Pasternak, to provide evidence about Chen's cultural background. Pasternak testified that it would not be unusual for an ordinary Chinese man to react violently if he found out his wife was being unfaithful. Distinguishing East Asian Chinese culture from Western American culture, Pasternak testified that it could be expected that a Chinese man would react more violently than someone from "our" society. Volpp notes that "the distinction [Chen's attorney] and Pasternak draw between 'American,' 'someone from our own society,' and 'Chinese' implies that 'Chinese' and 'American' are two utterly distinct categories: 'American' does not encompass immigrant Chinese." ${ }^{66}$ Volpp points out that when pressed, Pasternak "admitted he could not recall a single instance in which a man in China killed his wife or having ever heard about such an event, yet he suggested that this was accepted in China." ${ }^{\circ 7}$ Volpp points out that the defense strategy rendered Jian Wan Chen invisible. She was presented only 'as a dead body and as a reputed 'adulteress,' bringing a 'stain' upon her husband." 68

There are other resources that one can assign. In Individualizing Justice Through Multiculturalism: The Liberals' Dilemma ${ }^{69}$ Doriane Lambelet Coleman provides summaries of

\footnotetext{
${ }^{65}$ Leti Volpp, (Mis)Identifying Culture: Asian Women and the "Cultural Defense," 17 HARV. WoMEN's L.J. 57 (1994).

66 Id. at 66.

67 Id. at 70 .

68 Id. at 74-75.

${ }^{69}$ Doriane Lambelet Coleman, Individualizing Justice Through Multiculturalism: The Liberals' Dilemma, 96 CoLUM. L. REV. 1093 (1996).
} 
several additional cases in which the defendant used cultural evidence in his or her defense. She then invites debate over how to resolve what she calls the Liberals' Dilemma: how to balance "the defendant's interest in using cultural evidence that incorporates discriminatory norms and behaviors" against "the victims' and potential victims' interests in obtaining protection and relief through a non-discriminatory application of the criminal law."70 In A Justification of the Cultural Defense as Partial Excuse, Alison Dundes Renteln, the author of The Cultural Defense, ${ }^{71}$ offers several arguments in favor of the establishment of an official cultural defense. ${ }^{72}$

\section{Guerilla Guides to Law Teaching}

I would be remiss if I failed to mention the Guerilla Guide to Teaching Criminal Law, written by Jocelyn Simonson and Amna Akbar in 2016, part of the Guerilla Guides to Law Teaching project. $^{73}$

Among other things, Simonson and Akbar suggest that Criminal Law professors introduce the concept of abolition of the carceral state as a framework through which students can "question the core assumptions about the relationship between incarceration, retribution, and utilitarianism, and to take seriously the scale of human devastation wrought by incarceration." "74 Simonson and Akbar recommend that Criminal Law professors bring in "local organizers and movement folks to talk about their work on policing and mass incarceration." 75 They suggest that professors also "[b]ring in the voices and experiences of those directly impacted by the criminal justice system: those arrested, prosecuted, incarcerated." 76 They urge Criminal Law professors to "[t]alk about race, gender, and class as important dimensions of criminal justice that must be named, understood, and debated." 77 They also suggest that Criminal Law professors "[t]ake students to local criminal court to observe [court proceedings]" and "[s] how documentaries that provide a larger frame for the problems with criminal justice."78 They suggest assigning "narrative texts on the criminal justice system," such as Bryan Stevenson's book, Just Mercy: A Story of Justice and Redemption. ${ }^{79}$ They also suggest teaching misdemeanors and dedicating at least one full class to the subject of police violence as a complement to the unit on self-defense. ${ }^{80}$

\footnotetext{
70 Id. at 1097.

${ }^{71}$ Alison Dundes Renteln, The Cultural Defense (Oxford Univ. Press 2004).

72 Alison Dundes Renteln, A Justification of the Cultural Defense as Partial Excuse, 2 S. CAL. REV. L. \& WOMEN's STUD. 437 (1983).

73 Guerilla Guide to Teaching Criminal Law, available at https:/guerrillaguides.wordpress.com/2016/08/29/crimlaw/ [https://perma.cc/6LC2-8RQY]; Jocelyn Simonson \& Amna Akbar, Rethinking Criminal Law, L. \& PoL. Econ. (Oct. 24, 2018), https://lpeblog.org/2018/10/24/rethinkingcriminal-law/.

${ }^{74}$ Guerilla Guide to Teaching Criminal Law, supra note 73. For an important contemporary work that argues for abolition of prisons, one can assign an excerpt from PAUL BUtLeR, CHOKEHOLD: PoliCing BLACK MEN (2017). For background on mass incarceration as the new Jim Crow, one can assign an excerpt from MICHELLE ALEXANDER, THE NEW JiM CRow: MASS INCARCERATION IN THE AgE OF COLORbLINDNESS (2012).

${ }^{75}$ Guerilla Guide to Teaching Criminal Law, supra note 73.

${ }^{76}$ Id.

77 Id.

$78 / d$.

79 Id. (recommending Bryan SteVenson, Just Mercy: A Story of Justice AND RedeMPtion (Penguin Random House 2015)).

${ }^{80} / d$.
} 


\section{Final Words of Advice}

This chapter has suggested various ways law professors can incorporate discussions about race into the criminal law curriculum. While it is critically important to acknowledge the role of race in the criminal justice system and highlight the various ways racial bias can influence the outcomes in criminal cases, it is not necessary to include discussions of race in all of the different ways listed in this book chapter. Some professors are likely to face challenges in the classroom because of their race, ethnicity, gender, sexual orientation, and/or gender identity. Professors must also try to be sensitive to their audience. If one has students who are likely to presume one's incompetence as a law professor or be hostile to discussions involving race, one may need to first establish one's authority in the classroom. In such cases, I recommend that one start by teaching in a traditional fashion and establishing one's authority in the classroom before incorporating discussions about race into the classroom. 